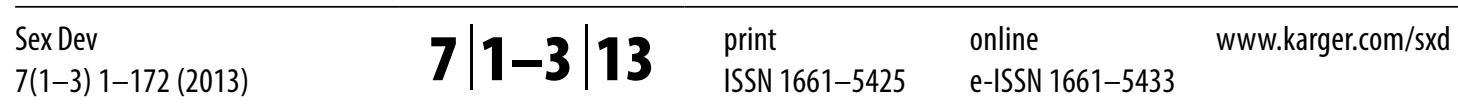

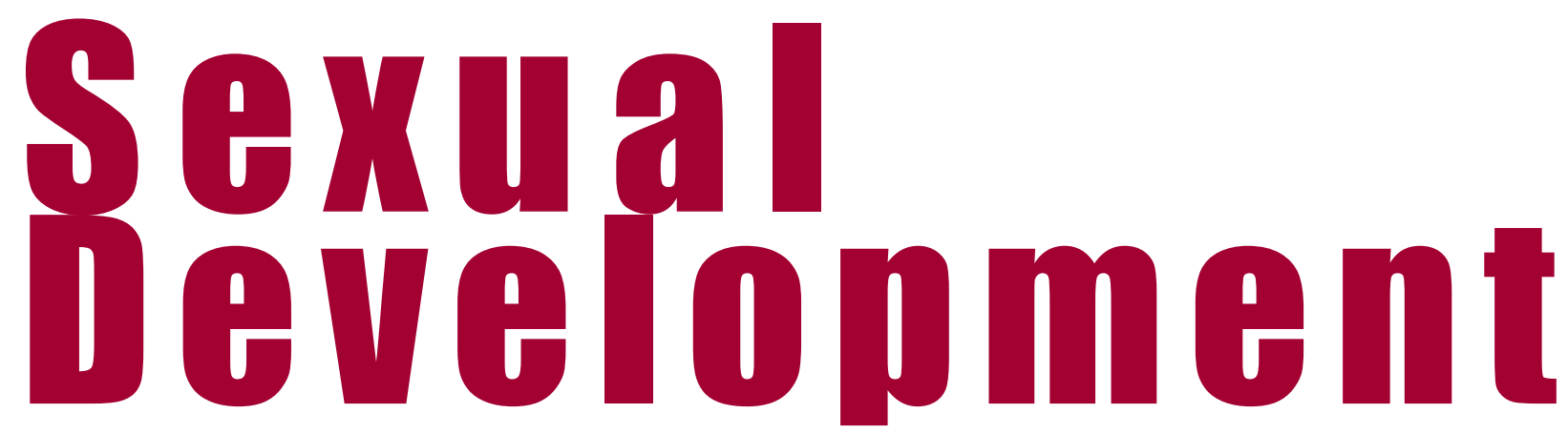

Genetics, Molecular Biology, Evolution, Endocrinology, Embryology and Pathology of Sex Determination and Differentiation

\title{
Control of Gonadal Development
}

Editor

R. Jiménez, Granada

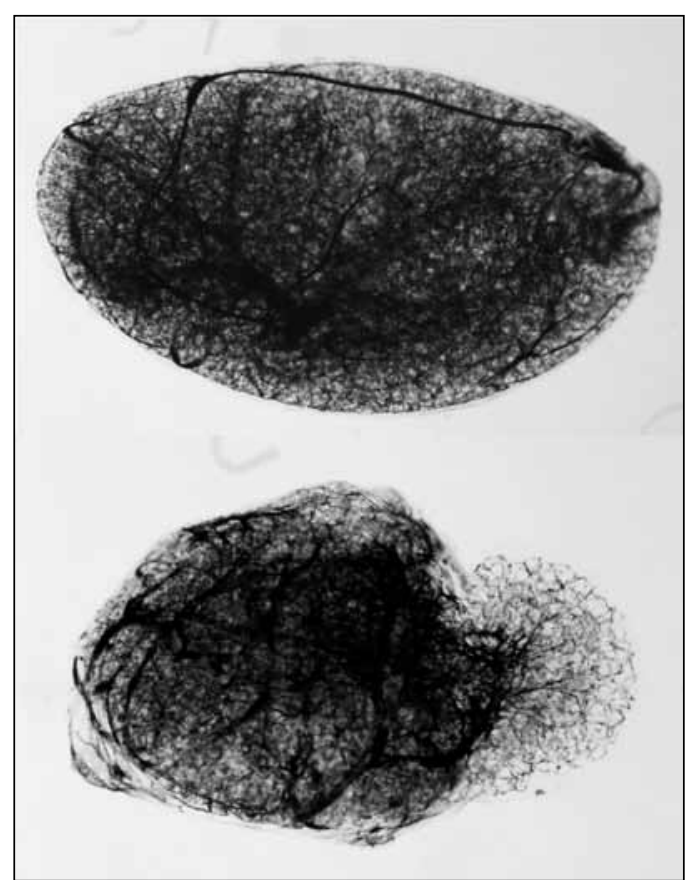




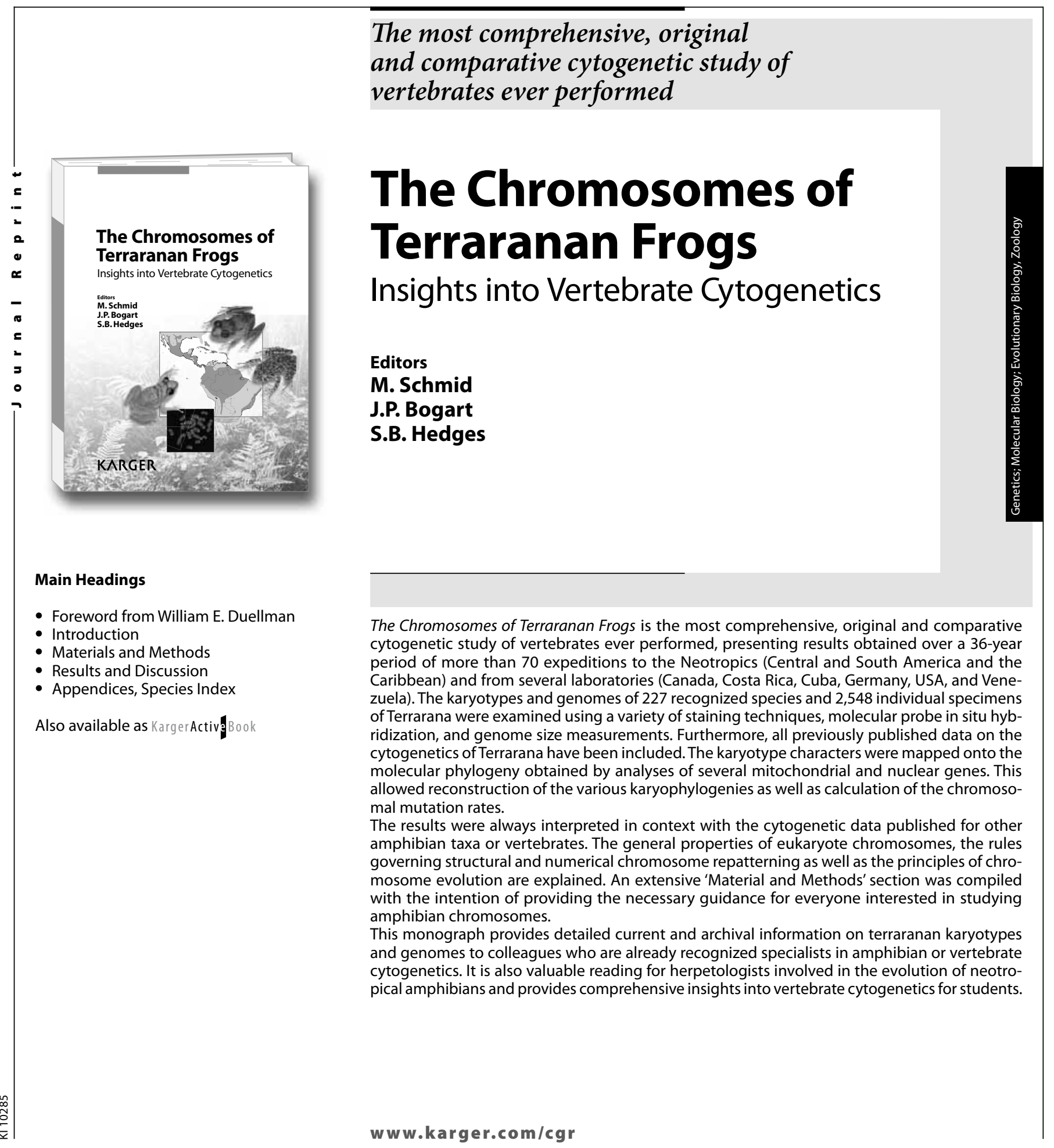

Cytogenetic and Genome Research Editor: Schmid, M. (Würzburg)

ISSN 1424-8581 / e-ISSN 1424-859X Hardcover reprint: Vol. 130-131/1-8 (2010)

The Chromosomes of Terraranan Frogs Insights into Vertebrate Cytogenetics Editors: Schmid, M. (Würzburg); Bogart, J.P. (Guelph, Ont.); Hedges, S.B. (University Park, Pa.) 568 p., 2071 fig., 162 in color, 18 tab., 5 appendices, hard cover, 2010

CHF 797.- / EUR 590.50 / USD 797.00

Prices subject to change

EUR price for Germany, USD price for USA only

ISBN 978-3-8055-9607-7

e-ISBN 978-3-8055-9608-4 $\rightarrow$ Please send: __ copy/ies

E

Postage and handling free with prepayment

Payment:

Please charge to my credit card

- $\square$ American Express $\square$ Diners $\square$ Eurocard

4 MasterCard

- Card No.

व

ర Exp date

-

- CVV/CVC

( 3 digits in the signature field on the back of Visa and MasterCard)

$\square$ Check enclosed $\quad \square$ Please bill me

Orders may be placed with any bookshop, subscription agency, directly with the publisher or through a Karger distributor.
Fax: +41 613061234

S. Karger AG, P.O. Box, CH-4009 Basel (Switzerland) E-Mail orders@karger.ch,www.karger.com

Name/Address: 
Genetics, Molecular Biology, Evolution, Endocrinology, Embryology and Pathology of Sex Determination and Differentiation

\section{Editors-in-Chief}

\section{Michael Schmid}

Department of Human Genetics

University of Würzburg

Biozentrum, Am Hubland

D-97074 Würzburg (Germany)

Tel. (+49) 931318 4077; Fax (+49) 9313184058

E-mail: m.schmid@biozentrum.uni-wuerzburg.de

\section{Managing Editors}

Martina Guttenbach (address as for M. Schmid) E-mail: guttenbach@biozentrum.uni-wuerzburg.de

Tanja Gösswein (address as for M. Schmid)

Mechthild Krämer (address as for M. Schmid)

E-mail: mechthild.kraemer@uni-wuerzburg.de

\section{Sections and Section Editors}

Genetics
Blanche Capel
Department of Cell Biology
4026 GSRBII, Box 3471
Duke University Medical Center
Durham, NC 27710 (USA)
Tel. (+1) 919684 6390; Fax (+1) 9196683467
E-mail: b.capel@cellbio.duke.edu

E-mail: b.capel@cellbio.duke.edu

\section{Molecular Biology}

David Zarkower

Department of Genetics, Cell Biology

and Development, University of Minnesota

6-160 Jackson Hall, 321 Church Street, SE

Minneapolis, MN 55455 (USA)

Tel. (+1) 612625 9450; Fax (+1) 6126267031

E-mail: zarko001@umn.edu

Patricia Y. Fechner

Division of Pediatric Endocrinology

University of Washington

Childrens Hospital and Regional Medical Center 4800 Sand Point Way NE

M1-3, Seattle, WA 98105 (USA)

Tel. (+1) 206987 2640; Fax (+1) 2069873700

E-mail: Patricia.Fechner@seattlechildrens.org

\section{Evolution}

\section{David Crews}

Section of Integrative Biology

University of Texas at Austin

Austin, TX 78712 (USA)

Tel. (+1) 512471 1113; Fax (+1) 5124716078

E-mail: crews@mail.utexas.edu

\section{Horacio Merchant-Larios}

Instituto de Investigaciones Biomedicas

Universidad Nacional Autonoma de Mexico

Apartado Postal 70228

Ciudad Universitaria

04510 Mexico, D.F. (Mexico)

Tel. (+1) 512471 1113; Fax (+1) 5124716078

E-mail: merchant@biomedicas.unam.mx

\section{Peter Koopman}

Institute for Molecular Bioscience

Brisbane, QLD 4072 (Australia)

Tel. (+61) 73346 2059; Fax (+61) 733462101

E-mail: p.koopman@imb.uq.edu.au
The University of Queensland

\author{
Manfred Schartl \\ Institute of Physiological Chemistry I \\ University of Würzburg \\ Biozentrum, Am Hubland \\ D-97074 Würzburg (Germany) \\ Tel. (+49) 931318 4148; Fax (+49) 9313184150 \\ E-mail: phch1@biozentrum.uni-wuerzburg.de
}

\section{Editorial Administrator}

Claus Steinlein (address as for M. Schmid)

E-mail: claus.steinlein@biozentrum.uni-wuerzburg.de

\section{Editorial Board Members}

Richard Behringer, Houston, TX

Silvano Bertelloni, Pisa

Linda A. Cannizzaro, New York, NJ

Eva M. Eicher, Bar Harbor, ME

Malcolm A. Ferguson-Smith, Cambridge

Vincent Harley, Melbourne

Paul-Martin Holterhus, Kiel

J. Larry Jameson, Chicago, IL

Lothar Just, Tübingen

Robin Lovell-Badge, London

Solange Magre, Paris

Yuji Mishina, Research Triangle Park, NC

Yoshitaka Nagahama, Okazaki

Serge Nef, Genève

Tsutomu Ogata, Tokyo

Eric Pailhoux, Jouy-en-Josas

Keith L. Parker, Dallas, TX

Marilyn B. Renfree, Melbourne

Rodolfo Rey, Buenos Aires

Turk Rhen, Grand Forks, ND

Andreas Schedl, Nice

Craig Smith, Parkville

Amanda Swain, London

Mark B. Van Doren, Baltimore, MD

Christoph Viebahn, Göttingen

Eric Vilain, Los Angeles, CA
Printed in Switzerland on acid-free and non-aging paper (ISO 9706) by Reinhardt Druck, Basel
Appears bimonthly: 1 volume per year (6 issues) 


\section{Aims and Scope}

Recent experimental and clinical research have led to impressive advances in our knowledge of the genetic and environmental mechanisms governing sex determination and differentiation, their evolution as well as the mutations or endocrine and metabolic abnormalities that interfere with normal gonadal development. The new journal 'Sexual Development' aspires to provide a unique forum for this rapidly expanding field. Its broad scope will cover all aspects of genetics, molecular biology, embryology, endocrinology, evolution and pathology of sex determination and differentiation in humans and animals. It will publish high-quality original research manuscripts, review articles, short reports, case reports and commentaries. 'Sexual Development' is a modern journal managed by an internationally renowned and multidisciplinary editorial team of three Chief Editors and ten prominent scientists serving as Section Editors, supported by a distinguished panel of editorial board members. They are committed to ensuring fast and author-friendly editorial processing and peer reviewing. Contributions from the scientific community are invited to make 'Sexual Development' the long-awaited and viable forum for basic and medical research on sex determination and differentiation.

\section{Sexual Development}

Publishes high-quality original reports and reviews covering all biological and clinical aspects of human and animal sexual determination and differentiation.

Categories of publications in conventional issues Original Articles are full reports in the following areas - Genetics • Molecular Biology • Evolution • Endocrinology • Embryology • Pathology of Sex Determination and Differentiation. Other categories closely related to the above topics could be considered by contacting the editors for approval.

Reviews covering a timely topic in the field are either invited by the Editors or may be submitted for consideration.

Short Reports must present results of sufficient importance to justify accelerated acceptance. They should take up no more than 3 printed pages in the journal and include a maximum of 2 figures, 1 table and 20 references. One printed text page corresponds to about 1,050 words or 5,700 characters.

Case Reports are for de novo observations of single cases with clinical or scientific significance. Reports of single mutations at genes, endocrine or metabolic abnormalities which have already been documented will be published only if they are of unusual clinical or biological interest. Brevity and clarity are always likely to enhance the chance of a manuscript being accepted for publication.

Commentaries is a forum for observations, opinions and comments outside the realm of conventional scientific papers. They should not be longer than 2 printed pages. Original data, and a maximum of 1 illustration and 1 table may be included. One printed text page in the journal corresponds to about 1,050 words or 5,700 characters.

\section{Single topic issues}

The journal will publish a series of thematic issues. For these volumes we are soliciting the assistance of one or more expert investigators to act as Guest Editor(s) in the area that is particularly interesting and/or in which there is a need for thorough overview. The Guest Editors invite top researchers to contribute original research reports or reviews on a topic that is in their main area of interest. These papers are peer reviewed in the same way as those received for the conventional issues. Proposals clearly outlining a theme and nominating potential Guest Editors are welcome.

\section{Special requirements}

Studies involving human subjects: 'Sexual Development' requires that investigations performed on human subjects have prior approval of the institutional committee on human experimentation. Authors are required to submit a signed statement concerning the date and details of the appropriate review. In countries where such mechanisms for approval do not exist, authors are required to submit a signed declaration that the research was carried out in accordance with the Helsinki Declaration.

Consent of patients: If there is any chance that a patient may be identified from an illustration, we ask for the written consent of the patient for publication (or where appropriate from his/her relatives or guardian). This will be so even if all the identifying details of the patient are removed. Data relating to anonymous tissue and other samples will not normally be considered to be personal information relating to a particular patient and publication of research findings connected with such samples does not require patient consent.

Studies involving animals: A statement is required to document that animal experimentation was performed under circumstances that conformed to the guidelines established by the animal care committees in the respective countries and/or institutions.

\section{Submission}

Papers should be submitted online at:

\section{www.karger.com/sxd}

Should you experience any problems with your submission, please contact the editorial office:

claus.steinlein@biozentrum.uni-wuerzburg.de

Claus Steinlein

Department of Human Genetics

University of Würzburg

Biozentrum, Am Hubland

D-97074 Würzburg (Germany)

Tel. (+49) 9313188091

Fax $(+49) 9318884058$

Authors should indicate which Section Editors they feel would be most appropriate for their report, and may also suggest up to three reviewers together with their e-mail addresses.

All manuscripts are subject to editorial review. The editors are committed to ensuring a fast turnaround time of 3 weeks for the review process. The editors reserve the right to improve style and, if necessary, return the manuscript for rewriting to the authors. The editorial office reserves rights to reject manuscripts based on priorities and space availability in the journal.

\section{Arrangement}

Papers must be prepared strictly in accordance with the style of this journal. The order in the paper must be: Title page, Abstract, Introduction, Materials and Methods, Results, Discussion, Acknowledgements, References, Figure legends, Figures, Tables.

Title page: The title page should give the full names of the authors and their affiliations, as well as full postal address, phone and fax numbers and the e-mail address of the corresponding author.

Abstracts with a maximum length of 250 words should be provided for all Original Articles and Reviews, and with 100 words for Short Reports and Case Reports.

Figures: Digital illustrations should be sharp with good contrast and color rendition. Resolution for all graphics should be at least 300 dots per inch. We request that all illustrations be in a common format such as .jpg (.jpeg .jpe), .tif (.tiff), .eps or .ppt.

Tables must be in Word format. Please use Microsoft Word Table $>$ Insert $>$ Table commands from the menu bar to make tables.

Literature cited: References should be quoted in the text as follows: single author: Jones (1999); two authors: Jones and Smith (2000); more than two authors: Jones et al. (2002). The reference list should be arranged alphabetically according to the first author's surname. Examples of citations are as follows: (1) Jones A, Smith B: The sex determining gene of Tyranosaurus rex. J Ext Rept 7:1-5 (2002). (2) Jones A: Pathology of Sex Determination in Parrots (Fantasy Press, London 1999). (3) Smith B: Evolution of the Mullerian duct, in White M, Black N (eds): Sex Differentiation in Kangaroos (Outback Press, Sydney 2003). Papers published in electronic format exclusively should list authors, title and journal as above followed by the journal's URL.

Agreement between text citations and the reference list should be checked carefully, and the latter checked for accuracy. If many errors are found, the manuscript will be returned for corrections which may cause considerable delay in publication.

Supplementary data may be submitted together with the manuscript, and will appear in their original form in the on-line version of the journal. The authors must refer to these data in their articles.

Gene/protein nomenclature: Authors must use officially approved gene/protein designations and check out every single gene/protein name before placing them in their papers.

Human gene symbols: Only official gene symbols of the International System for Genome Nomenclature (ISGN) are accepted. Authors must obtain or verify the official gene symbol of the gene(s) and indicate that they have done so in the submitted paper. This can be accomplished for human genes by contacting Dr. Sue Povey (HUGO Gene Nomenclature Committee), Department of Biology, University College London, Wolfson House, 4 Stephenson Way, London, NW1 $2 \mathrm{HE}$ (UK); Tel. +44 207679 7410; Fax +44 2073873496 E-Mail nome@galton.ucl.uk; URL: www.gene.ucl. ac.uk/nomenclature/

Animal gene symbols: Authors submitting material on mouse and rat genetics should obtain correct genetic nomenclature before publication. Contact Lois Maltais, MGD Nomenclature Coordinator, The Jackson Laboratory, 600 Main Street, Bar Harbour, ME 04609 (USA); Tel. +1 207288 6429; Fax +1 207288 6132; E-Mail nomen@informatics.jax.org; MGD homepage: www.informatics.jax.org. Guidelines set forth by the International Committee on Standardized Ge-

\section{KARGER}

Fax +4161306 1234 E-Mail karger@karger.ch www.karger.com
(C) 2013 S. Karger AG, Basel 
netic Nomenclature for Mice are available at www. informatics.jax.org/mgihome/nomen/table.shtml New symbols and names for genes can be requested electronically via the on-line addresses given above.

\section{Electronic Proofs}

Unless indicated otherwise, proofs will be e-mailed to the corresponding author.

Reprints of the articles are available against payment Order forms listing prices are provided with the proofs. If no reprints are desired this should be indicated on the order form. Orders submitted after the issue has gone to press are subject to higher prices.

\section{Supplementary Material}

Supplementary material is restricted to additional data that are not necessary for the scientific integrity and conclusions of the paper. Please note that all supplementary files will undergo editorial review and should be submitted together with the original manuscript. The Editors reserve the right to limit the scope and length of the supplementary material. Supplementary material must meet production quality standards for Web publication without the need for any modification or editing. In general, supplementary files should not exceed $10 \mathrm{MB}$ in size. All figures and tables should have titles and legends and all files should be supplied separately and named clearly. Acceptable files and formats are: Word or PDF files, Excel spreadsheets (only if the data cannot be converted properly to a PDF file), and video files (.mov, .avi, .mpeg).

\section{Author's Choice ${ }^{\mathrm{TM}}$}

Karger's Author's Choice ${ }^{\mathrm{TM}}$ service broadens the reach of your article and gives all users worldwide free and full access for reading, downloading and printing at www.karger.com. The option is available for a onetime fee of CHF 3000.-, which is a permissible cost in grant allocation. More information can be found at www.karger.com/authors_choice.

\section{NIH-Funded Research}

The U.S. National Institutes of Health (NIH) mandates under the NIH Public Access Policy that final, peer-reviewed manuscripts appear in its digital database with in 12 months of the official publication date. As a service to authors, Karger submits the final version of your article on your behalf to PubMed Central. For those selecting our premium Author's Choice ${ }^{\mathrm{TM}}$ service, we will send your article immediately upon publishing, accelerating the accessibility of your work without the usual embargo. More details on NIH's Public Access Policy is available at http://publicaccess.nih.gov/policy.htm

\section{Self-Archiving}

Karger permits authors to archive their pre-prints (i.e. pre-refereeing) or post-prints (i.e. final draft post-refereeing) on their personal or institution's servers, provided the following conditions are met: Articles may not be used for commercial purposes, must be linked to the publisher's version, and must acknowledge the publisher's copyright. Authors selecting Karger's Author's Choice ${ }^{\mathrm{TM}}$ feature, however, are also permitted to archive the final, published version of their article, which includes copyediting and design improvements as well as citation links.

\section{KARGER BOOKS ON MEDICAL PHILOSOPHY}

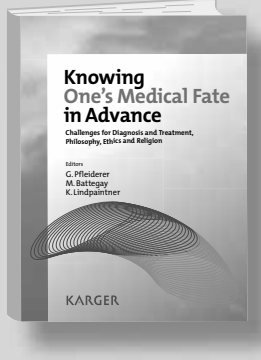

\section{Knowing One's} Medical Fate in Advance Challenges for Diagnosis and Treatment, Philosophy, Ethics and Religion

Editors: G. Pfleiderer, M. Battegay, K. Lindpainter

$\mathrm{VI}+122$ p., 4 fig., 2 in color, hard cover, 2012

CHF 59. - /EUR 49. - /USD 69.00

ISBN 978-3-8055-9649-7

The certainty and uncertainty of one's fate are discussed from both methodological and epidemiological perspectives, using examples of diseases for which treatment and prognosis have dramatically changed. Despite profound insights into the human genome, personalized genetically tailored medicine still lies in the future. Religious, spiritual and philosophical dimensions are discussed, as are the ways in which they may help people cope with these new insights into their future, e.g. the promise of an afterlife.

This publication aims to bridge the different fields dealing with this area by addressing the challenges faced and encouraging dialogue. It will be of interest to all readers who deal with ethical problems of prognosis, particularly in medicine, as well as to theologians and sociologists.

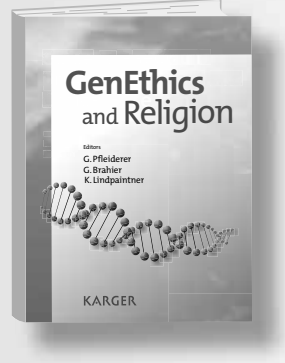

\section{GenEthics and Religion}

Editors: G. Pfleiderer, G. Brahier K. Lindpaintner

$\mathrm{VI}+154 \mathrm{p}$., hard cover, 2010

CHF 29.- / EUR 24.- / USD 34.00

ISBN 978-3-8055-8973-4

Prices subject to change

EUR price for Germany, USD price for USA only

\section{KARGER}

Based on the symposium 'GenEthics and Religion' (Basel, Switzerland, May 2008), this volume examines the role religion can play in establishing ethical guidelines to protect human life in the face of rapid advances in biology and gene technology. It does so with contributions by philosophers, theologians, human geneticists, and several bioethicists representing the Christian, Jewish, Islamic and Buddhist perspectives. The essays illustrating a diversity of views and expressing the problems and self-critical reflectiveness of religious ethicists are brought up to date and discuss the importance of religious ethics in society's discourse on gene technology.

$\mathrm{KI} 12281$

\section{KARGER}

Fax +41 613061234

E-Mail karger@karger.ch

www.karger.com
(C) 2013 S. Karger AG, Basel

The Guidelines for Authors are available at:

www.karger.com/sxd_Guidelines 
ISSN Print Edition: 1661-5425

ISSN Online Edition: 1661-5433

Journal Homepage: www.karger.com/sxd

Publication Data: 'Sexual Development' is published 6 times a year. Volume 7 with 6 issues appears in 2013 .

Copyright: () 2013 S. Karger AG, Basel (Switzerland). All rights reserved. No part of this publication may be translated into other languages, reproduced or utilized in any form or by any means, electronic or mechanical, including photocopying, recording, microcopying, or by any information storage and retrieval system, without permission in writing from the publisher or, in the case of photocopying, direct payment of a specified fee to the Copyright Clearance Center.

Disclaimer: The statements, opinions and data contained in this publication are solely those of the individual authors and contributors and not of the publisher and the editor(s). The appearance of advertisements in the journal is not a warranty, endorsement, or approval of the products or services advertised or of their effectiveness, quality or safety. The publisher and the editor(s) disclaim responsibility for any injury to persons or property resulting from any ideas, methods, instructions or products referred to in the content or advertisements.
Subscription Rates: Subscriptions run for a full calendar year. Prices are given per year. Personal subscription:

Print or Online

CHF 178.-

EUR 144.-

USD 176.00

Print+Online combined CHF 226.-

EUR 183.-

USD 224.00

postage and handling (added to print and print+online)

CHF 43.20 Europe, CHF 62.40 Overseas

EUR 33.60

USD 57.60

Institutional subscription

Print or Online

Print+Online combined

CHF 1666.-

EUR 1344.-

CHF 1833.-

USD 1650.00

USD 1815.00

postage and handling (added to print and print+online)

CHF 54.- Europe, CHF 78.- Overseas

EUR 42.-

USD 72.00

Airmail surcharge: CHF 52.50 / USD 49.50

Discount subscription prices:

Please enquire about reduced rates for members of affiliated societies.
Back Volumes and Single Issues: Information on availability and prices of single print issues and print or electronic back volumes can be obtained from Customer Service atservice@karger.ch.

Bibliographic Indices: This journal is regularly listed in bibliographic services, including Current Contents ${ }^{\circledR}$ and PubMed/MEDLINE.

Photocopying: This journal has been registered with the Copyright Clearance Center (CCC), as indicated by the code appearing on the first page of each article. For readers in the US, this code signals consent for copying of articles for personal or internal use, or for the personal or internal use of specific clients, provided that the stated fee is paid per copy directly to

Copyright Clearance Center Inc.

222 Rosewood Drive

Danvers, MA 01923 (USA)

A copy of the first page of the article must accompany payment. Consent does not extend to copying for general distribution, for promotion, for creating new works, or for resale. In these cases, specific written permission must be obtained from the copyright owner,

S. Karger AG, P.O. Box

CH-4009 Basel (Switzerland).
Subscription Orders:
Orders can be placed at agencies,

bookstores, directly with the Publisher

\section{S. Karger AG}

Medical and Scientific Publishers

P.O. Box

CH-4009 Basel

Switzerland

(for courier services only:

Allschwilerstrasse 10

CH-4055 Basel)

t: +416130611 11

f: +41613061234

e: karger@karger.ch

w: www.karger.com or further Karger offices

or representatives:

Germany

S. Karger GmbH

Postfach

79095 Freiburg

Deutschland

(Hausadresse: Wilhelmstrasse 20A

79098 Freiburg)

$\mathrm{t}: \quad+49761452070$

f: $\quad+497614520714$

e: information@karger.de

w: www.karger.de

Japan

Karger Japan, Inc

Shiba Daimon Asahi Bldg. 2F

1-2-23 Shiba Daimon

Minato-ku

Tokyo 105-0012

Japan

t: +81364356242

f: +81364356244

e: publisher@karger.jp

w: www.karger.jp

Change of Address:

Both old and new address should be sent to the subscription source.

USA

S. Karger Publishers, Inc.

26 West Avon Road

P.O. Box 529

Unionville, CT 06085

USA

Toll free: +18008285479

t: +18606757834

f: +18606757302

e: karger@snet.net

France

Librairie Médi-Sciences Sarl

36, bd de Latour-Maubourg

75007 Paris

France

t: $+33(0) 145514258$

f: $+33(0) 145560780$

f: $+33(0) 145560780$
e: librairie@medi-sciences.fr

w: www.medi-sciences.fr

Gulf Council Countries, Iran,

Middle East, North Africa, Turkey

Trans Middle East International

Distribution Co. Ltd. (KaSha)

168 B, King Abdullah the 2nd Street

Daboog Building 2nd Floor

Daboog Area

P.O. Box 2376

Amman 11953

Jordan

t: +962 65153467

$\mathrm{t}:+96265153467$
$\mathrm{f}:+96265411336$

e: info@kasha.cc

w: www.KaShaonline.com
South East Asia, China and Taiwan Karger Regional Office (Malaysia) CEO Suite Kuala Lumpur Quill 7, 27th Floor

Jalan Stesen Sentral 5

KL Sentral

Kuala Lumpur 50470

Malaysia

t. +60327766803

f: +60327766999

e: service@karger.cn; r.chew@karger.cn

\section{Karger China}

10th Floor, Twin Towers (East)

B12 Jianguomenwai Avenue

Beijing 100022

China

$\mathrm{t}: \quad+861051235033$

f: +861051235122

e: service@karger.cn; r.chew@karger.cn

w: www.karger.cn

India, Bangladesh, Sri Lanka

Medscience India

Plot No. 17, Yusuf Sarai Market

B.L. Glass Building, 2nd Floor

Sri Aurobindo Marg

New Delhi 110016

India

t: +911146029633

f: +911146029634

c: +919891052128

e: medsci.india@gmail.com

\section{KARGER}

Fax +41 613061234

E-Mail karger@karger.ch

www.karger.com
(C) 2013 S. Karger AG, Basel

The Journal Home Page is available at:

www.karger.com/sxd 


\section{Contents}

See the journal website for contents

KARGER Basel $\bullet$ Freiburg $\cdot$ Paris $\bullet$ London $\bullet$ New York $\cdot$ New Delhi $•$ Bangkok Beijing $\cdot$ Tokyo $\cdot$ Kuala Lumpur $\cdot$ Singapore $\bullet$ Sydney 


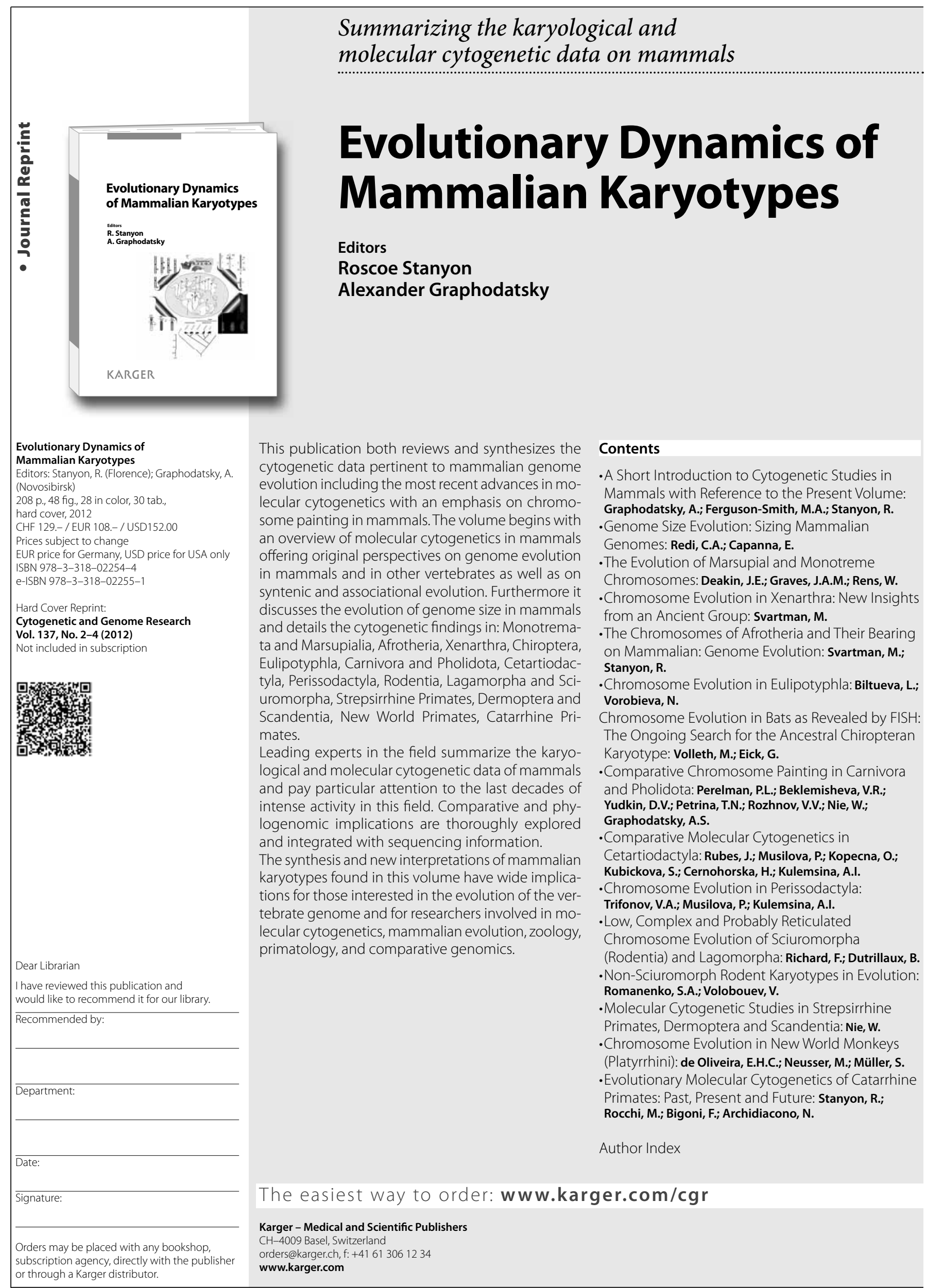




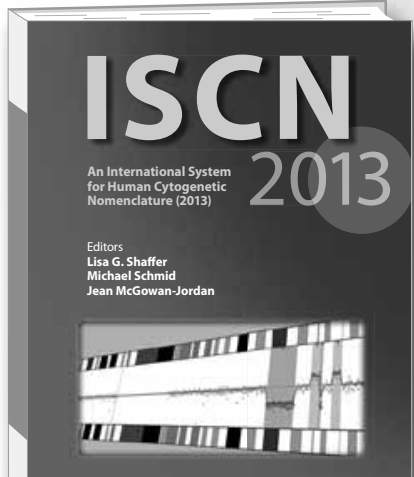

KARGER
ISCN 2013

An International System for Human Cytogenetic Nomenclature (2013)

\author{
Editors \\ Lisa G. Shaffer \\ Jean McGowan-Jordan \\ Michael Schmid
}

\section{ISCN 2013}

An International System for

Human Cytogenetic Nomenclature (2013)

Recommendations of the International

Standing Committee on Human Cytogenetic

Nomenclature

Published in collaboration with

'Cytogenetic and Genome Research'

Editors: Shaffer, L.G. (Spokane, Wash.);

McGowan-Jordan, J. (Ottawa, Ont.); Schmid, M.

(Würzburg)

VI + 140 p., 11 fig., 4 tab., soft cover, 2013

Plus fold-out: 'The Normal Human Karyotype $\mathrm{G}$ - and R-bands'

CHF 43.- * EUR 30.50* / USD 43.00*

Prices subject to change

EUR price for Germany, USD price for USA only ISBN 978-3-318-02253-7

Dear Librarian

I have reviewed this publication and would like to recommend it for our library. Recommended by:

Department:

Date:

Signature:

Orders may be placed with any bookshop, subscription agency, directly with the publisher or through a Karger distributor.
This publication extends the now classic system of human cytogenetic nomenclature prepared by an expert committee and published in collaboration with 'Cytogenetic and Genome Research'since 1963. Revised and finalized by the ISCN Committee and its advisors at a meeting in Seattle, Wash., in April 2012, the ISCN 2013 updates, revises and incorporates all previous human cytogenetic nomenclature recommendations into one systematically organized publication that supersedes all previous ISCN recommendations.

There are several new features in ISCN 2013:

- an update of the microarray nomenclature, many more illustrative examples of uses of nomenclature in all sections

- some definitions including chromothripsis and duplication

- a new chapter for nomenclature that can be used for any region-specific assay.

The ISCN 2013 is an indispensable reference volume for human cytogeneticists, technicians and students for the interpretation and communication of human cytogenetic nomenclature.

\section{Main Headings}

- Historical Introduction

- Normal Chromosomes

- Symbols and Abbreviated Terms

- Karyotype Designation

- Uncertainty in Chromosome or Band Designation

- Order of Chromosome Abnormalities in the Karyotype

- Normal Variable Chromosome Features

- Numerical Chromosome Abnormalities

- Structural Chromosome Rearrangements

- Chromosome Breakage

- Neoplasia

- Meiotic Chromosomes

- In situ Hybridization

- Microarrays

- Region-Specific Assays
1 copy: CHF 43.- / EUR 30.50 / USD 43.00 each 2 copies: CHF 41.- / EUR 29.50 / USD 41.00 each 3-4 copies: CHF 40.- / EUR 28.50 / USD 40.00 each 5-9 copies: CHF 38.- / EUR 27.- / USD 38.00 each 10-19 copies: CHF 34.- / EUR 24.50 / USD 34.00 each 20+ copies: CHF 32.- / EUR 23.- / USD 32.00 each 


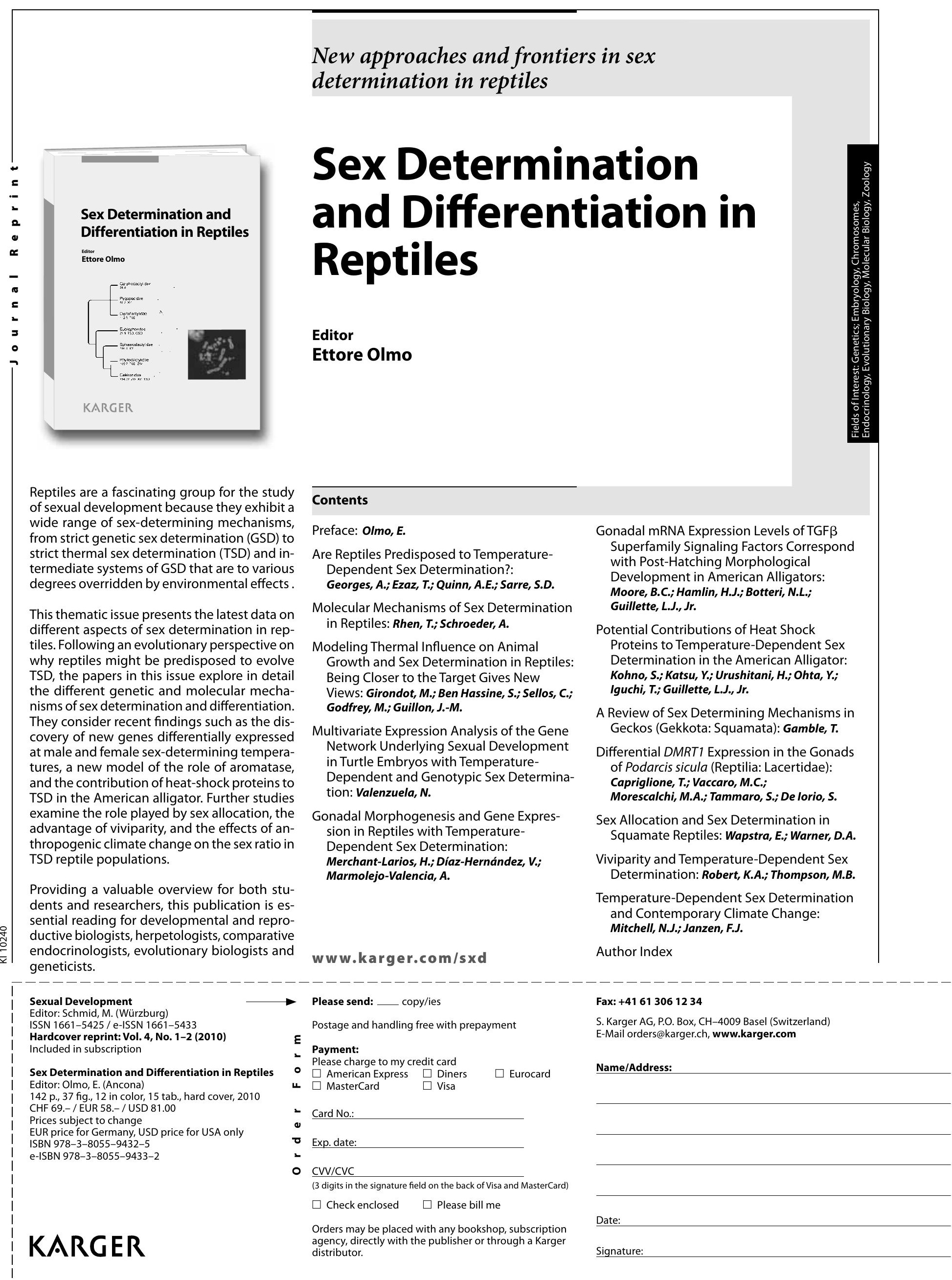


Make plans now to attend the 2013 ACMG Annual Clinical Genetics Meeting to be held March 19-23 in Phoenix, Arizona. Outstanding networking opportunities with peers and worldwide leaders and an exhibition featuring the most current products and services available makes this the one scientific meeting in 2013 that can't be missed.

CALL FOR ABSTRACTS: Electronic online Abstract submission opens in October at www.acmgmeeting.net.

SUBMISSION DEADLINE: December 7, 2012

EARLY BIRD REGISTRATION: December 19, 2012 ～ADVANCE REGISTRATION: February 13, 2013

Session topics include:

- 2013 ACMG Presidential Plenary and Awards Presentation

- 44th Annual March of Dimes Clinical Genetics Conference: Genetics of Skeletal Dysplasias and Connective Tissue Disorders (Presented in honor of Founding President and Genetics Pioneer, the late David L. Rimoin, MD, $\mathrm{PhD}, \mathrm{FACMG}$ )

- Highlights Plenary Session

- Closing Plenary Session: Reimbursement for Genomic Medicine in 2013 and Beyond

- Advances in Classification, Genetic Diagnosis and Understanding of Arthrogryposis and Related Fetal Movement Disorders

- Birth Defects and Dysmorphic Features from Inborn Errors of Metabolism - Basic Mechanisms and Practical Clinical Approaches to Recognition and Evaluation

- Birth Defects and Dysmorphic Features from Inborn Errors of Metabolism

- Moving Clinical Genomics into Advanced Diagnostic and Personalized Therapeutics for Cancer and Beyond

- Cardinal Signs and Symptoms of Inborn Errors of Metabolism in the Adult

- Cardinal Signs of Syndromes

- Diagnostic Dilemmas (Rare Knowns and Unknowns)

- From Screening to Treatment: A Paradigm Shift in Understanding Fragile X and FMRI Disorders

- Homozygosity: Perspectives in the Genomics Era (Funded by the ACMG Foundation's Father Robert C. Baumiller Fund for Genetics and Society)

- Integrating Exome Sequencing into Clinical Practice

- Updates in Neurogenetics

- R. Rodney Howell Symposium: Fifty Years of Newborn Screening: Impact on the Practice of Genetics and Genomics

- Reproductive Genetics: Issues from Preconception Through the Prenatal Period

- Whole Genome Analysis Consent and Prenatal Findings: An Open Forum on Return of Genetics Results

- Workshop on Preparing Effective Evidence-based Guidelines in Genetics

\section{Other Program Highlights:}

- Genetic Counselor's Forum and Luncheon

- CME Short Courses

- Next Generation Sequencing From a Clinical Perspective: What Are You Getting and What Does it Mean

- Arrays, NIPT and Expanded Carrier Screening: Advances and Controversies in Prenatal Genetics

- Industry Supported Satellite Sympoisa

- Careers in Medical Genetics - An Informational Session for Students - A special half-day session designed for undergraduates and medical school students

- Special programming and events for Students, Trainees, Residents, Post-Doctoral and Clinical Fellows

\section{$\mathrm{ACMG}$}

American College of Medical Genetics and Genomics Translating Genes Into Health ${ }^{\circ}$

Sponsored and accredited by the American College of Medical Genetics and Genomics in conjunction with the 44th Annual March of Dimes Clinical Genetics Conference: Skeletal Dysplasias and Connective Tissue Disorders

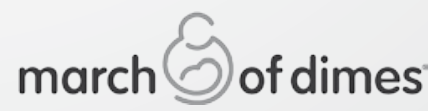




\section{Novel insights from basic research to clinical practice}

\section{HORMONE RESEARCH IN PAEDIATRICS}

HORMONE RESEARCH IN PAEDIATRICS

Editor
P. Czernichow, Paris
Associate Editors

S. Bernasconi, Parma

F. Chiarelli, Chieti

M.T. Dattani, London

0. Hiort, Lübeck
L. Ibañez, Barcelona

P.E. Mullis, Bern

M.A. Rivarola, Buenos Aires

P. Saenger, Bronx, N.Y.

0. Söder, Stockholm

J.M. Wit, Leiden
Official Journal of the

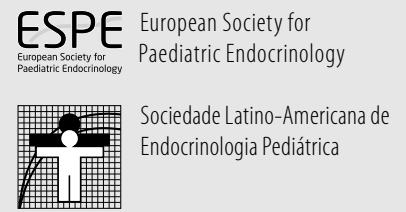

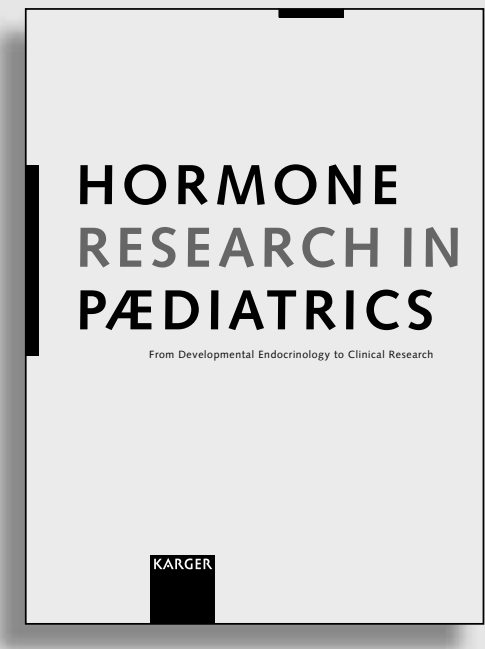

More information at

www.karger.com/hrp

- Pay-per-View and Subscriber Access to Full Text

- Full Table of Contents

- Full Editorial Board

- Free Abstracts and Selected Articles

- Online Sample Issue

- Submission/Guidelines for Authors

- Subscription Details

- Free Alert Service

- Online Library Recommendation

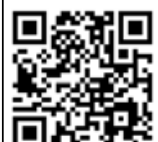

Hormone Research in Paediatrics

2013: Volumes 79, 80

6 issues per volume

Language: English

ISSN 1663-2818 (print)

ISSN 1663-2826 (online)

\section{Selected contributions}

- Genome-Wide Association Studies in Pediatric Endocrinology: Dauber, A.; Hirschhorn, J.N. (Boston, Mass.)

- Mechanisms of Growth Plate Maturation and Epiphyseal Fusion: Emons, J. (Leiden); Chagin, A.S.; Sävendahl, L. (Stockholm); Karperien, M. (Enschede); Wit, J.M. (Leiden)

- Observed and Predicted Total Pubertal Growth during Treatment with Growth Hormone in Adolescents with Idiopathic Growth Hormone Deficiency, Turner Syndrome, Short Stature, Born Small for Gestational Age and Idiopathic Short Stature: KIGS Analysis and Review: Ranke, M.B. (Tübingen); Lindberg, A. (Sollentuna) on behalf of the KIGS International Board

- The Genetics of 3-M Syndrome: Unravelling a Potential New Regulatory Growth Pathway: Hanson, D.; Murray, P.G.; Black, G.C.M.; Clayton, P.E. (Manchester)

- Effects of Prenatal Ethanol Exposure on Postnatal Growth and the Insulin-Like Growth Factor Axis: Aros, S. (Santiago); Mills, J.L. (Bethesda, Md.); Iñiguez, G.; Avila, A. (Santiago); Conley, M.R.; Troendle, J.; Cox, C. (Bethesda, Md.); Cassorla, F. (Santiago)

- Renaissance of Brown Adipose Tissue: Tews, D.; Wabitsch, M. (Ulm)

- The Predictive Value of the Individual Components of the Metabolic Syndrome for Insulin Resistance in Obese Children: Vos, R.C.; Houdijk, E.C.A.M. (The Hague); van der Kamp, H.J.; Pijl, H.; Wit, J.M. (Leiden)

- Growth Hormone//GF-I Axis and Growth Hormone Receptor Mutations in Idiopathic Short Stature: El Kholy, M. (Cairo); Mella, P. (Brescia); Rashad, M. (Cairo); Buzi, F. (Brescia); Meazza, C. (Pavia); Zahra, S.; Elsedfy, H.H. (Cairo)

- Natural History of Idiopathic Advanced Bone Age Diagnosed in Childhood: Pattern of Growth and Puberty: Lazar, L. (Petah Tikva/Tel Aviv); Lebenthal, Y. (Petah Tikva); Shalitin, S.; Phillip, M. (Petah Tikva/Tel Aviv)
With some of the greatest advances from developmental endocrinology to clinical research being achieved as a direct result of close collaboration between basic and clinical investigators, Hormone Research in Paediatrics facilitates the interchange of ideas by placing findings at all levels and from all branches side by side in a single source. Original research papers provide a background of experimental data on the pathology, cytology, histology, biochemistry, pharmacology and regulation of hormones. This information is complemented by authoritative reports drawing on clinical experiences concerning the many diagnostic and therapeutic procedures and possibilities. In particular, such topical problems as growth, diabetes, sexual development and tumours of endocrine origin are covered in depth. As a bonus for subscribers, the journal also features frequent supplement issues. 


\section{Sexual Development}

\section{Control of \\ Gonadal Development}

Sex determination, the mechanism by which embryos are committed to develop as either males or females, has been the subject of intense research during the last two decades. Gonadal development, which is a crucial event of sex differentiation, involves complex cellular processes, including the differentiation of several cell types, cell proliferation and migration as well as vascularization, which take place differently in male and female embryos. This special issue of Sexual Development presents a series of 12 articles describing the state of the art of the control of gonad development in mammals and other vertebrates. Several of the most renowned international experts in the field of sexual development review the genetic, hormonal and environmental operators controlling gonad development in mammals, birds, reptiles, amphibians, fish and nematodes, as well as the cases of sex reversal and gonad abnormalities derived from mutations in the human and other mammals.

Providing both basic and advanced insights into the control of gonad development in a variety of animal taxa, this issue is essential reading for both students and researchers in the fields of genetics, developmental and reproductive biology, zoology and evolutionary biology. 